\title{
Sedimentation and sediment geochemistry in a tropical mangrove channel meander, Sungai Kerteh, Peninsular Malaysia
}

\author{
Hasrizal Shaari ${ }^{1,2^{*}}$ (D), Qatrunnada Mohd Nasir ${ }^{1}$, Hui-Juan Pan ${ }^{3,4^{*}}$, Che Abd Rahim Mohamed ${ }^{5}$, Abdul Hafidz Yusoff ${ }^{6}$, \\ Wan Mohd Afiq Wan Mohd Khalik, Erick Naim², Riza Yuliratno Setiawan ${ }^{7}$ and Edward J. Anthony ${ }^{8,9}$
}

\begin{abstract}
Tropical mangrove swamps are commonly characterized by dense networks of tidal channels that may show pronounced meandering and dendritic patterns. Channel meanders are sometimes accompanied by cut-offs, and, like classical fluvial meanders, record changes in hydrology and sedimentation over time. Channel meandering can, thus, be an important process that contributes to spatial and temporal variability in the preserved record of the sedimentology and geochemistry of mangrove sediments. The aim of this study is to highlight changes in channel meander sedimentation in response to a meander cut-off in a tropical mangrove swamp. Two short sediment cores were sampled, respectively from a point bar (core KR1, $122 \mathrm{~cm}$ ) at the junction with the neck cut-off and inside the cut-off (core KR2, $98 \mathrm{~cm}$ ) in the Sungai Kerteh mangroves of Peninsular Malaysia. The profile comparison was based on sediment characteristics, total organic carbon (TOC), and selected elements ( $\mathrm{Fe}, \mathrm{Na}, \mathrm{Mg}, \mathrm{Mn}, \mathrm{Ba}$, and Sr). A smaller standard deviation of mean grain size (MGS) was found at the point bar ( $4.37 \pm 0.51 \varphi$ ) than in the cut-off $(4.43 \pm 1.76 \varphi)$, indicating a difference in flow velocity between the two settings. In turn, these changes in grain size influence channel meander evolution via associated changes in TOC and heavy metals. In order to clarify these relationships, we used principal components analysis and factor analysis. An increased accumulation of selected elements and TOC at the cut-off site from a depth of $\sim 60 \mathrm{~cm}$ to the core-top segment was probably associated with a slowing down of sediment settling. A higher TOC recorded in the cut-off ( $2.74 \pm 1.42 \%)$ compared to the point bar $(1.14 \pm 0.46 \%)$ suggests a propensity for prolonged in situ accumulation of organic matter in the abandoned meander bend. This study provides grain size and sediment geochemical information that is consistent with patterns of active and inactive sedimentation in the meander bends of mangrove channels.
\end{abstract}

Keywords: Mangrove, Tidal channel meander, Mangrove geochemistry, Mangrove sedimentation

\section{Introduction}

Tidal channels in mangroves are important pathways for the transport of sediments, dissolved oxygen, nutrients, seedlings, and organic matter (Woodroffe 1992; Anthony 2009). Tidal network types and densities are highly variable, ranging from meandering to dendritic patterns,

\footnotetext{
*Correspondence: riz@umt.edu.my; hjpan76@gmail.com

${ }^{1}$ Faculty of Science and Marine Environment, Universiti Malaysia Terengganu, 21030 Kuala Nerus, Terengganu, Malaysia

${ }^{3}$ Institute of Earth Science, College of Ocean Science and Resource, National

Taiwan Ocean University, Keelung, Taiwan

Full list of author information is available at the end of the article
}

and, as noted by Allen (2000) for saltmarsh systems, they reflect several linked natural factors that are not well known, especially in comparison to the better known fluvial networks. One source of complexity is the bidirectional tidal flow, in comparison to the unidirectional flow in fluvial systems. As in the case of classical fluvial meanders (Leopold and Wolman 1960; Ferguson 1984; Howard 2009), however, mangrove channel meanders are expected to record changes in channel hydrology and sedimentation over time. Meandering is formed by river flow momentum alternations from side to side 
within a channel, commonly across the floodplain, but the process is also inherent to shifting channels within a valley (Edwards and Smith 2002). Meanders are dynamic systems that can be far from equilibrium, driven by complex linear and nonlinear processes (Argyris et al. 1994). Theoretically, the flow erodes sediment at the outside of a bend as it reaches a maximum velocity. The eroded materials are deposited as a point bar on the inside of the bend. These processes can lead to obstruction of flow at the neck, resulting eventually in the formation of a new shorter channel, a meander cut-off, and neck abandonment. Cut-offs have been considered as having an important role in shaping river meander landscapes by leading to the isolation of meander bends and perturbing the local dynamics (Hooke 1977; Camporeale et al. 2008; Schwenk and Foufoula-Georgiou 2016). In mangroves and saltmarshes, entrenched tidal channel networks are deemed to evolve very slowly through processes that include meander-bend erosion and sedimentation, with subsequently, very slow change of these inherited forms over multi-decadal to centennial timescales (Anthony 2009). Understanding these processes in mangrove forests can contribute to an understanding of changing present environments, under natural and human-induced processes that drive mangrove sedimentation, as well as of the paleo-environmental record (e.g., França et al. 2015; Cohen et al. 2016; Woodroffe et al. 2016). However, elucidation of these processes and the eventual messages that can be deduced regarding environmental changes can only be achieved through archives provided by sediment cores (e.g., Ellison and Stoddart 1991; Ellison and Farnsworth 1997). Such sedimentary archives provide a record of the type, rates, and patterns of sedimentation. Access to such information requires, however, both a classical sedimentological approach as well as geochemical characterization. Potential differences in sedimentation on meander convex banks and correlative erosion on meander concave banks have been evoked to explain differences in the vigor and health of mangroves that are generally clearly visible on aerial photographs and satellite images (Anthony 2004). We know of no work, however, that has been undertaken to highlight the impact of channel meander evolution on mangrove sedimentation and on the sediment geochemistry. In this paper, we document changes in mangrove channel meander sedimentation associated with a meander cutoff in a Malaysian mangrove system (Fig. 1) using grain-size and geochemical characteristics of core sediments in the vicinity of an abandoned meander. We show that such sedimentological and geochemical characterization can be used in identifying change in mangrove environments.

\section{Methods/experimental}

\subsection{Study site}

The mangroves of Sungai Kerteh are located in Kemaman District, Terengganu, Peninsular Malaysia (Fig. 1). The dominant mangroves are Rhizophora apiculata and
Avicennia sp. A major morphological feature of the area is the Kerteh River, a coastal river approximately $23 \mathrm{~km}$ long that originates in hilly terrain at $\sim 350 \mathrm{~m}$ above sea level, before running through the mangroves and entering the sea just north of Kerteh Town. The Kerteh receives runoff from a number of smaller upstream tributaries. The lower reaches of the Kerteh are influenced by semi-diurnal tides. The tidal range in the area is mesotidal, ranging from $0.2 \mathrm{~m}$ at low tide to $3.3 \mathrm{~m}$ at high tide during spring tides (PHN 2019). There are no data on water discharge of the Kerteh River, which is modulated seasonally by Monsoon rainfall (mean annual: $\sim 2800 \mathrm{~mm}$ ) and at shorter timescales by the springneap tidal range.

The tidal reaches of the Kerteh River display prominent meanders typical of mature mangrove swamps that are probably characterized by low substrate sedimentation rates, as suggested by the morphological stability of the channels. Locally, however, this stability has been affected or enhanced by embankments associated with villages and communities located on the channel banks. According to the classification by Jackson (1978), the present Kerteh channel can be considered as muddy fine-grained, with a low width/depth ratio, steep point bar slopes, and prominent levees. The study site is a mangrove swamp comprising a meander with a cut-off upstream of Kampung Gelugor (Fig. 1). The abandoned meander segment displays a straight, nearly $1 \mathrm{~km}$-long cut-off channel. Sediments were sampled at two different locations in the mangroves (Fig. 1): the neck cut-off (core KR1) and the inside of the meander (core KR2). The KR1 site is located at the confluence of two tidal channels, one of which included the cut-off reach with sampling site KR2. The dominant species at KR1 is Rhizophora apiculata whereas KR2 consists of mixed Avicennia sp. and Rhizophora apiculata.

\subsection{Sampling and sample pre-treatment}

The two cores were collected at low tide by driving a $2.5 \mathrm{~m}$ polyvinyl chloride (PVC) tube with a diameter of $6.5 \mathrm{~cm}$ into the mangrove sediment. A tight cable and rope were attached to the middle part of the PVC tube in order to retrieve it from the mangrove. A cork and plastic were used to cover the top of the tube neatly to create a vacuum condition, enabling slow and cautious recovery of the cores. The pull-out process was conducted carefully to reduce loss of sample material and to maintain the lithological structure of the core sediment. The collected core samples were immediately processed in order to reduce the compaction effects. The lengths of core KR1 and core KR2 were $122 \mathrm{~cm}$ and $98 \mathrm{~cm}$, respectively. Samples from both cores were cut and split into two segments. Each segment was sliced at $2 \mathrm{~cm}$ intervals, yielding a total of 61 samples for KR1 and 49 


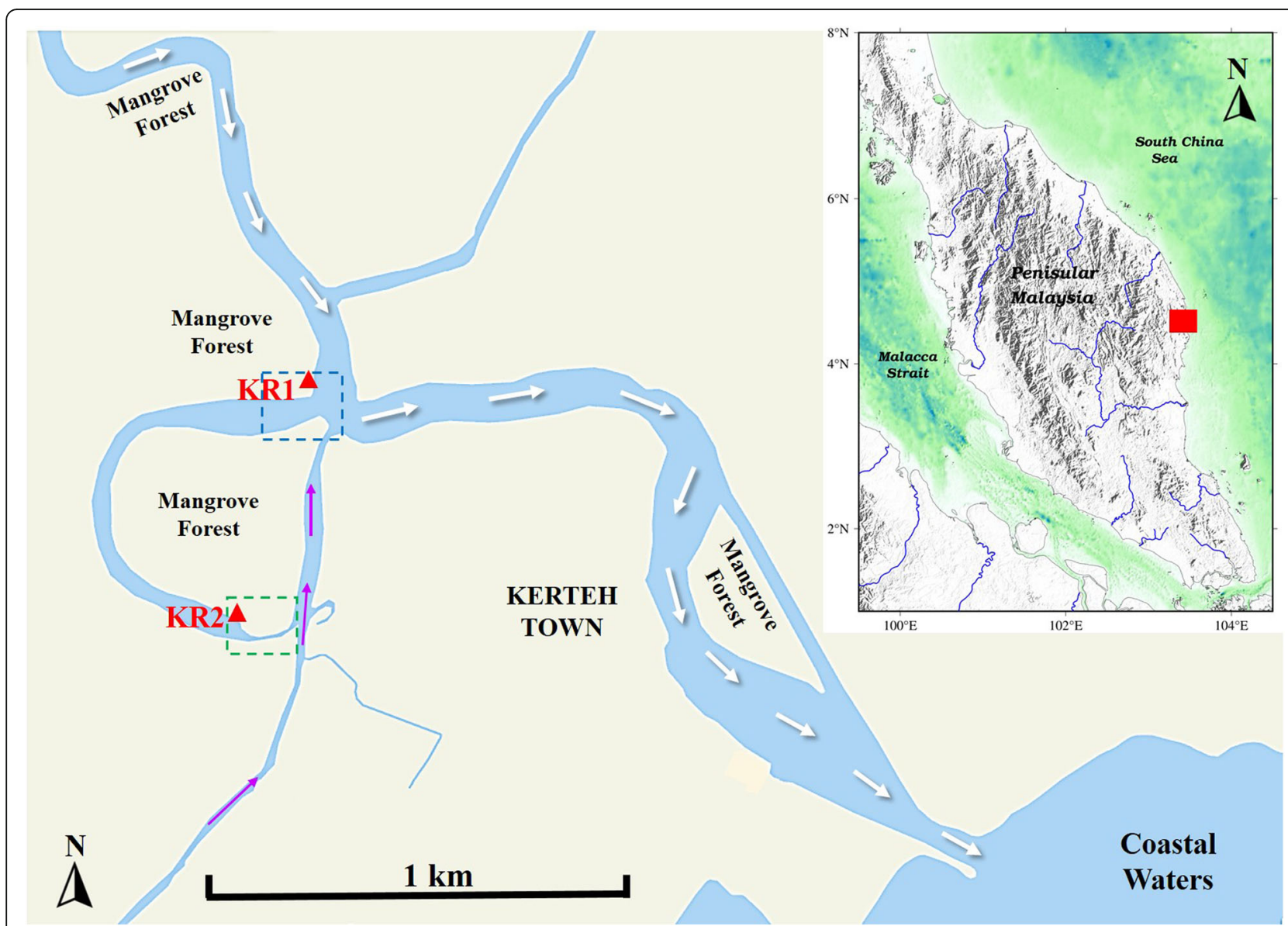

Fig. 1 Map showing the Kerteh mangrove forest in Peninsular Malaysia and the locations of cores KR1 (4 31' 27. 5" N, 103' 26' 25.91" E) and KR2 $\left(4^{\circ} 31^{\prime} 10.98^{\prime \prime} \mathrm{N}, 103^{\circ} 26^{\prime} 19.68^{\prime \prime} \mathrm{E}\right)$. The white arrows indicate the river flow directions of main water body of Sungai Kerteh from upstream toward the tidal channel and pink arrows indicate the river flow direction from small branch of Sungai Kerteh. The blue dash box indicates the cutoff location and the pale green dash box indicates new mangrove vegetation at the old river's pathway due to the active sedimentation process (source: Google Earth)

samples for KR2. In order to avoid contamination, the samples were stored in clean-labeled vinyl bags in the laboratory before analyses of grain size, metal content, and total organic carbon were carried out. The samples were oven dried at $50^{\circ} \mathrm{C}$ and powdered using an agate mortar with a pestle for further analysis except for sediment characteristics and grain size.

\subsection{Sediment characteristics}

Approximately $5 \mathrm{~g}$ of the sediment samples were transferred into a $100 \mathrm{ml}$ beaker and diluted with distilled water as a medium for the digestion process. A few drops of hydrochloric acid $(\mathrm{HCl})$ and $15 \%$ of hydrogen peroxide $\left(\mathrm{H}_{2} \mathrm{O}_{2}\right)$ were added into the beaker to remove carbonate content and organic materials. Calgon solution ( $20 \%$ sodium thiosulphate) was added and acted as an agent to disperse the samples into single particles. The samples were left at room temperature for $24 \mathrm{~h}$ to allow complete particle dispersion. Sediment samples were analyzed using a laser diffraction analyzer (MALV ERN Mastersizer 2000). All data collected were subjected to statistical analysis using the moments statistical method (Friedman and Johnson 1982). Grain-size characteristics (particle mean grain size and sorting) were calculated using the formula of Folk and Ward (1957). The relative proportions of sand, silt, and clay were determined using the textural triangle proposed by USDA (1987).

\subsection{Total organic carbon}

The total organic carbon was determined based on the Walkley-Black chromic acid wet oxidation method (Walkley and Black 1934; Allison and Moodie 1965). Approximately, $10 \mathrm{ml}$ of potassium dichromate was added to $0.5 \mathrm{~g}$ of sample in a test tube. Then, $20 \mathrm{ml}$ of sulfuric acid was added and left in a beaker of boiling water $(30 \mathrm{~min})$. The test tube was rinsed with $200 \mathrm{ml}$ of distilled water into a conical flask and $10 \mathrm{ml}$ of 
phosphoric acid with a $1 \mathrm{ml}$ diphenylamine indicator added. The solution was mixed until it turned dark blue. Finally, ferum (II) sulfate was titrated until the solution turned green and the total volume of ferum (II) sulfate was recorded. The calculation of organic carbon content was as follows:

TOC $(\%)=(\mathrm{V} 1-\mathrm{V} 2) \times 0.03 \times 100 /$ sample weight $(\mathrm{g})$ where,

$\mathrm{V} 1$ = volume of potassium dichromate $(\mathrm{ml})$

$\mathrm{V} 2$ = volume of ferum (II) sulfate $(\mathrm{ml})$

A set of blanks and standard research material (SRM) dextrose monohydrate was applied in every batch of sample analysis in order to determine the background content of organic carbon and as a control on the analysis. The standard percentage value of total organic carbon in dextrose monohydrate is $36 \%$, while the average percentage of measured dextrose monohydrate of the analysis was $36 \pm 1.2 \%$. The crosscheck with three replicates at every $10 \mathrm{~cm}$ core depth for both core samples was also set up in the analysis to ensure the results are credible and acceptable.

\subsection{Metal analysis}

Sample digestion followed the published methods of Noriki et al. (1980) and Kamaruzzaman (1999) with the modification of mixed acid ratio and digesting temperature. Approximately, $0.05 \mathrm{~g}$ of homogenized samples were digested in a concentrated mixed acid ratio of $\mathrm{HF}, \mathrm{HNO}_{3}$, and $\mathrm{HCl}(2: 3.5: 3.5)$ in a sealed Teflon vessel at $100{ }^{\circ} \mathrm{C}$ for $7 \mathrm{~h}$. After cooling to room temperature, a clear digested solution was transferred into a $15 \mathrm{ml}$ polypropylene test tube and diluted with deionized water. An inductively coupled plasma mass spectrometer (ICP-MS) was used for the precise determinations of selected heavy metals (Fe, $\mathrm{Mg}, \mathrm{Cu}, \mathrm{Mn}, \mathrm{Ba}$, and $\mathrm{Sr}$ ). The accuracy of the analytical procedure was assessed by analyzing standard research material in duplicate from the National Bureau of Standard (NBS) 1646a. The recovery test coincided with the certified values of NBS 1646a. The recovery percentage of measured metals was found to be acceptable, ranging between $86.99 \%$ and $109.50 \%$ (Table 1).

\subsection{Principal components analysis and factor analysis}

Principal components analysis and factor analysis were used to highlight relationships among the variables. The main component was extracted using principal component analysis through the eigen-decomposition method. Factor analysis was used to explain the latent variables rendered in the data sets using Varimax method after Kaiser normalization. Factor loading scores were categorized as follows: VF $>0.75$ (strong), $0.75<\mathrm{VF}>0.5$ (moderate), and $<0.50$ (weak), corresponding to the absolute varifactor values (Liu et al. 2003). The statistical data processing and analysis were generated by using the
Table 1 The value of accuracy analysis for standard reference of trace elements

\begin{tabular}{llll}
\hline Trace element & Certified value & Analysis value & Percentage (\%) \\
\hline Fe $(\%)$ & $2.01 \pm 0.04$ & $2.20 \pm 0.10$ & 109.5 \\
Mg $(\%)$ & $0.40 \pm 0.01$ & $0.39 \pm 0.27$ & 97.5 \\
Mn $(\mathrm{mg} / \mathrm{kg})$ & $234.5 \pm 2.80$ & $204.0 \pm 17.7$ & 86.99 \\
$\mathrm{Sr}(\mathrm{mg} / \mathrm{kg})$ & 68 & 65.2 & 95.88 \\
\hline
\end{tabular}

software Minitab version 17 (Minitab Inc., State College, USA).

\section{Results and discussion}

\subsection{Particle mean size and sorting, and sediment facies}

Figure 2a shows the mean grain size (MGS) of sediment against depth for cores KR1 and KR2. Values ranged from $3.47 \phi-5.92 \phi$ for KR1 and $1.52 \phi-6.47 \phi$ for KR2. The highest and lowest MGS values in KR1 were recorded at depths of $32 \mathrm{~cm}$ and $52 \mathrm{~cm}$, respectively. For KR2, the highest and lowest values occurred at depths of $56 \mathrm{~cm}$ and $82 \mathrm{~cm}$. The profile of MGS in KR2 showed a significant change at $60 \mathrm{~cm}$ depth. Figure $2 \mathrm{~b}$ shows the sorting values of sediment in both cores. KR1 ranged between 0.44 (moderately sorted) and 2.61 (moderately well-sorted). The values of KR2 were between 1.60 and 2.30 (moderately sorted and moderately well-sorted). The average value in KR2 was $1.60 \pm 2.34 \varnothing$ with the highest value at $66 \mathrm{~cm}(2.61 \varnothing)$ and the lowest at $0.44 \varnothing$. In KR1, the mean was $0.44 \pm 2.61 \varnothing$ with the highest value at a depth of $32 \mathrm{~cm}(2.34 \varnothing)$ and the lowest value at $102 \mathrm{~cm}(1.60 \varnothing)$. The best-sorted sediment was recorded at a depth of $80 \mathrm{~cm}$ in core KR1. As in the case of MGS, sorting also showed the same trend with depth. Figure 3 shows a textural classification plot of sediment in the two cores. The sediments in KR1 from the point bar exhibit a high percentage of sand (40 to $80 \%$ ) in contrast to sediment from KR2 from the meander cut-off which is less sandy (10 to $40 \%$ ).

\subsection{Total organic carbon}

The TOC was determined in KR1 and KR2 (Fig. 2c). The TOC content was significantly higher in core KR2 ranging from $0.6-5.5 \%$ as compared to core KR1 with values of $0.24-4.26 \%$. The average TOC values in core $\mathrm{KR} 2$ and KR1 were $2.74 \% \pm 1.42 \%$ and $1.14 \% \pm 0.46 \%$ (Fig. 2c). There were two obvious trends between TOC contents of cores KR1 and KR2. Like the metal and MGS trends, there were two apparent trends for TOC content in both core samples. The TOC content fluctuated from the bottom of the core toward the surface with no significant changes for core KR1. On the other hand, the content in core KR2 was only comparable to that of core KR1 at depths between $98 \mathrm{~cm}$ and $76 \mathrm{~cm}$. The concentration of TOC drastically increased at a 

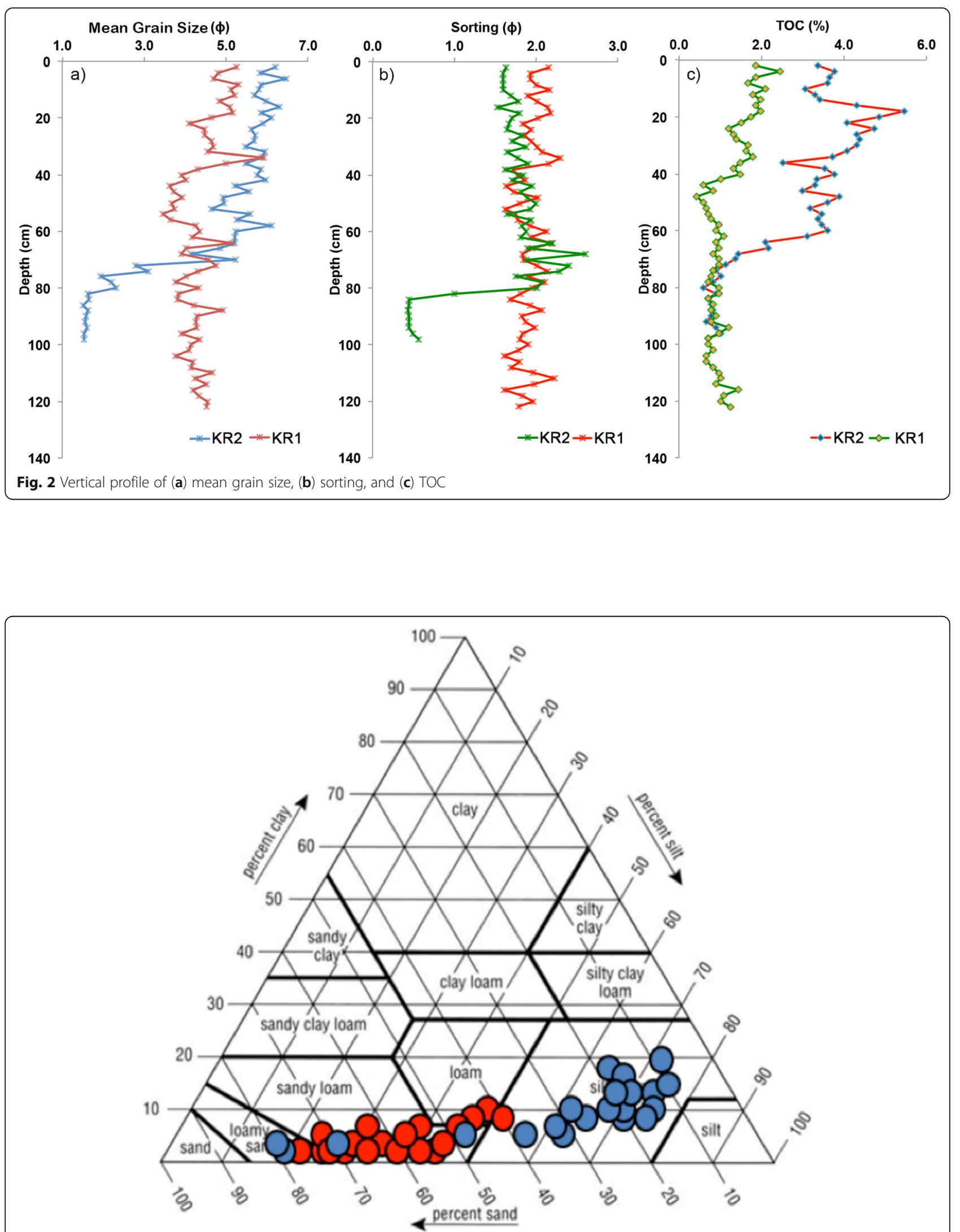

Fig. 3 Textural classification of sediment from KR1 (red dots) and KR2 (blue dots) 
depth of $72 \mathrm{~cm}$ and remained high up to the surface of the core.

\subsection{Metals}

The element concentrations in core KR1 varied from 0.32 to $2.18 \%(\mathrm{Fe}), 0.51$ to $2.38 \%(\mathrm{Na}), 0.49$ to $0.95 \%$ (Mg), 81.60 to $204.00 \mathrm{mg} / \mathrm{kg}(\mathrm{Mn}), 22.40$ to $47.60 \mathrm{mg} / \mathrm{kg}$ (Ba), and 1.37 to $7.98 \mathrm{mg} / \mathrm{kg}$ (Sr) (Fig. 4). The average concentrations of $\mathrm{Fe}, \mathrm{Na}, \mathrm{Mg}, \mathrm{Mn}, \mathrm{Ba}$, and $\mathrm{Sr}$ were 1.25 $\pm 0.30 \%, 1.21 \pm 0.77 \%, 057.92 \mathrm{mg} / \mathrm{kg}, 63.01 \pm 15.49 \mathrm{mg} /$ $\mathrm{kg}, 17.48 \pm 2.14 \mathrm{mg} / \mathrm{kg}$, and $9.1 \pm 1.5 \mathrm{mg} / \mathrm{kg}$. The element concentrations in core KR2 varied from 0.07 to $2.24 \%$ for Fe, 0.30 to $2.14 \%$ for $\mathrm{Na}, 0.01$ to $0.71 \%$ for $\mathrm{Mg}$, 5.34 to $173.80 \mathrm{mg} / \mathrm{kg}$ for $\mathrm{Mn}, 3.20$ to $34.20 \mathrm{mg} / \mathrm{kg}$ for $\mathrm{Ba}$, and 0.50 to $6.52 \mathrm{mg} / \mathrm{kg}$ for Sr. The average concentrations of elements in this study followed the order of $\mathrm{Fe}>$ $\mathrm{Na}>\mathrm{Mg}>\mathrm{Mn}>\mathrm{Ba}>\mathrm{Sr}$. In general, the selected element content in KR1 did not show an abrupt change from

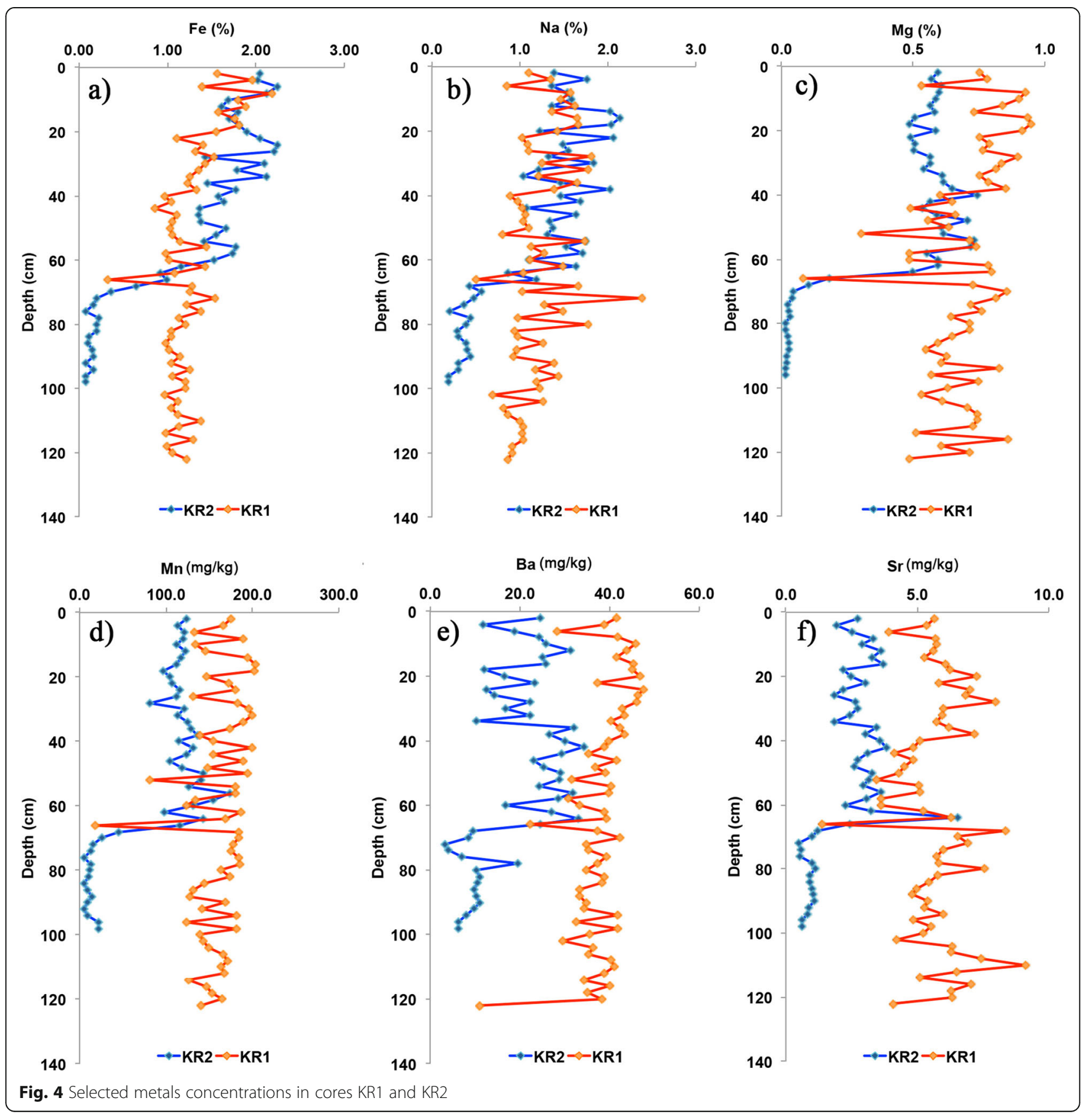


the bottom toward the surface. However, the element content in the core KR2 showed a significant increase at a depth of $\sim 70 \mathrm{~cm}$.

The grain-size characteristics and selected aspects of the geochemistry of sediment cores in the vicinity of a mangrove tidal channel meander bend in Malaysia highlight an abrupt change in channel hydrodynamic and sedimentation regimes following a meander cut-off. The straight, nearly $1 \mathrm{~km}$-long cut-off channel (Fig. 1) points out to a rather abrupt hydrological change, rather than being the product of the slow progressive rapprochement of two opposite channel segments that eventually coalesced to form a cut-off. A scrutiny of available aerial photographs and Google Earth images shows that the Kerteh cut-off has been extant over at least the last 13 years. The cut-off may well have occurred during the big flood event that hit Terengganu nearly a century ago from 21 to 29 December 1926, accompanied by exceptional rainfall (1944 $\mathrm{mm}$ compared to the annual mean of $\sim 2800 \mathrm{~mm}$ ), and resulting in severe environmental damage and the destruction of thousand hectares of forests (Chan 2012; Williamson 2016).

Whatever the true age of the cut-off, the change engendered by this event is recorded in the grain-size and TOC trends. Sediment particle characteristics have been shown to provide information on the relationship between hydrodynamics and transport or deposition (e.g., Droppo et al. 2015). The dominantly fine-grained nature of the sediments found in KR1 and KR2, composed essentially of silts and, to a lesser degree, clays (Figs. 2, 3), reflects both the high degree of weathering of tropical soils and the effect of mangrove swamps on dampening water flows and favoring the accumulation of mud. Notwithstanding, differences in grain size have been found between the two cores in the Kerteh swamp. Core KR2 shows, in particular, a very sharp transition from coarse, through fine to medium sand, at a depth of about $80 \mathrm{~cm}$, to relatively homogeneous silt and clay in the rest of the upper part of the core. We attribute this sharp change to the transition from an active channel meander to meander cut-off. Meander cut-offs in tidal environments have been shown to exhibit sharp upward changes in facies following abandonment (e.g., Anthony et al. 1996). The coarse basal deposits correspond to sand deposited in an active channel bed. Once the cut-off occurred, the diversion of flows through the straight new channel was accompanied by a shift to fine-grained deposits associated with settling in a low-energy, abandoned channel environment. The grain size in KR1 is relatively more homogeneous, though the upper part of the core (above $70 \mathrm{~cm}$ ) shows a clearly overall fining trend. This characteristic may reflect a shift from relatively more coarsergrained sedimentation at the base to more continuously finer-grained point-bar sedimentation. The differences between the two cores are less manifest in sorting, with the exception of basal sediments in the point bar which show poor sorting, probably reflecting mixing of sediment in an energetic channel environment. It may be surmised that the abrupt change in sorting in this core may pinpoint the time of the meander cut-off. Fleming (2017) identified a tendency for sorting to be homogeneous in sediment composed of a similar range of size, whereas poor sorting implies sediment mixing with different sizes of sediment.

The abrupt variation in grain size and sedimentation rate in the meander cut-off is also consistent with an increase in OC, thus, further reflecting the consequences of this event on local sedimentation. The grain size influence on channel meander evolution is embedded not only in these changes in OC but also in heavy metals. Both particle size distribution and $\mathrm{OC}$ concentrations changed significantly at $\sim 70 \mathrm{~cm}$, pointing to a change in the depositional environment. Meander cut-offs in tidal flats have been shown to be depocenters of organic matter following the instauration of quiescent hydrodynamic conditions, as flow becomes diverted through the cutoff, and the abandoned meander belt may also become progressively covered by vegetation (Anthony et al. 1996). This situation also concerns the Kerteh meander belt which appears to be progressively invaded by mangroves (Fig. 1). This increase in OC has also been shown to go with a decrease in grain size (Sutherland 1999). Generally, OC binds more easily with fine sediment, clay, or silt.

Previous studies have shown that the distribution of heavy metals in sediment is closely related to organic matter and mostly depends on the type of sediment (Karbassi et al. 2005; Abdul Razak et al. 2018). The metal concentration in the point bar is almost uniform from the bottom to the top of the core, whereas the concentration in the cut-off shows a clear transition phase at a depth of $70 \mathrm{~cm}$, thus, further providing evidence for a morpho-sedimentary change in the Kerteh channel associated with meander cut-off. The abandonment of the meander created conditions for the active accumulation of elements and OC in the cut-off, compared to the point bar. Louma (1990) has shown this relationship between the concentration of elements and sedimentation processes. The variability in metal concentration has also been shown to depend on the size and texture of sediments (Jicknells and Kump 1984; Ramos et al. 1994), with larger mean grain size being associated with a larger variation of metal concentration at the same area (Morse et al. 1993).

In order to further clarify the relationships in the grain size and geochemistry of these deposits, we used a correlation coefficient matrix for each core (KR1: Table 2; KR2: Table 3). The correlation of metals with mean 
Table 2 Correlation coefficient between MGS, TOC, and selected metals in core KR1

\begin{tabular}{lllllllll}
\hline & MGS & TOC & $\mathrm{Fe}$ & $\mathrm{Na}$ & $\mathrm{Mg}$ & $\mathrm{Mn}$ & $\mathrm{Ba}$ & $\mathrm{Sr}$ \\
\hline MGS & 1 & & & & & & & \\
TOC & 0.71 & 1 & & & & & & \\
$\mathrm{Fe}$ & 0.60 & 0.71 & 1 & & & & & \\
$\mathrm{Na}$ & 0.30 & 0.30 & 0.59 & 1 & & & & \\
$\mathrm{Mg}$ & 0.46 & 0.50 & $\mathbf{0 . 7 6 ^ { \mathrm { H } }}$ & 0.58 & 1 & & & \\
$\mathrm{Mn}$ & $\mathbf{0 . 1 8 ^ { \mathrm { L } }}$ & 0.20 & 0.48 & 0.41 & 0.73 & 1 & & \\
$\mathrm{Ba}$ & 0.27 & 0.36 & 0.53 & 0.40 & 0.78 & 0.56 & 1 & \\
$\mathrm{Sr}$ & 0.24 & 0.15 & 0.42 & 0.41 & 0.74 & 0.56 & 0.59 & 1 \\
\hline
\end{tabular}

$H$ highest correlation, $L$ lowest correlation

grain size and TOC in cut-off was relatively stronger compared to the point bar. The highest correlation value of the latter is 0.76 (Fe-Mg), followed by $\mathrm{Fe}-\mathrm{Cu}(r=$ $0.75), \mathrm{Cu}-\mathrm{Sr}(r=0.74), \mathrm{Mg}-\mathrm{Mn}(r=0.73)$, mean sediment-TOC $(r=0.71)$, and TOC-Fe $(r=0.71)$. The highest correlation value of the cut-off is $r=0.98(\mathrm{Mg}$ $\mathrm{Mn})$, whereas the lowest correlations occur between $\mathrm{Ba}-$ Fe $(=0.59)$ and Ba-TOC $(r=0.53)$, although both are still considered as strongly correlated to each other. The strong positive correlation between all parameters in the cut-off suggests that grain size is an important criterion for the attachment of metals and TOC under the conditions of reduced flow energy that ensued following meander abandonment. Nguyen et al. (2005) have shown that highly correlated metals exhibited a similar behavior in the study area. Generally, the contents decreased as grain size increased.

Principal components analysis (PCA) highlighted two significant compounds (eigenvalue $>1$ ) that explained 71.2\% (KR1) and 93.0\% (KR2) of the total variance of the datasets (Table 4). For KR1, varifactor VF1 explained $28.3 \%$ of the total variance in the datasets with positive loadings on metal content such as $\mathrm{Mg}(0.89), \mathrm{Mn}(0.79)$, $\mathrm{Ba}(0.75)$, and $\mathrm{Sr}(0.86)$. Varifactor VF2 accounted for $32.8 \%$ of the total variance with positive loadings on

Table 3 Correlation coefficient between MGS, TOC, and selected metals in core KR2

\begin{tabular}{lllllllll}
\hline & MGS & TOC & $\mathrm{Fe}$ & $\mathrm{Na}$ & $\mathrm{Mg}$ & $\mathrm{Mn}$ & $\mathrm{Ba}$ & $\mathrm{Sr}$ \\
\hline $\mathrm{MGS}$ & 1 & & & & & & & \\
TOC & 0.89 & 1 & & & & & & \\
$\mathrm{Fe}$ & 0.92 & 0.94 & 1 & & & & & \\
$\mathrm{Na}$ & 0.88 & 0.88 & 0.89 & 1 & & & & \\
$\mathrm{Mg}$ & 0.92 & 0.86 & 0.91 & 0.89 & 1 & & & \\
$\mathrm{Mn}$ & 0.89 & 0.83 & 0.89 & 0.84 & $\mathbf{0 . 9 8 ^ { \mathrm { H } }}$ & 1 & & \\
$\mathrm{Ba}$ & 0.66 & $\mathbf{0 . 5 3 ^ { \mathrm { L } }}$ & 0.59 & 0.68 & 0.83 & 0.81 & 1 & \\
$\mathrm{Sr}$ & 0.74 & 0.63 & 0.66 & 0.72 & 0.86 & 0.85 & 0.90 & 1 \\
\hline
\end{tabular}

$H$ highest correlation, $L$ lowest correlation
Table 4 Varifactors of varimax rotated loading results

\begin{tabular}{|c|c|c|c|c|c|c|}
\hline \multirow[t]{2}{*}{ Variable } & \multicolumn{3}{|l|}{ KR1 } & \multicolumn{3}{|l|}{ KR2 } \\
\hline & VF1 & VF2 & Communality & VF1 & VF2 & Communality \\
\hline Depth & -0.07 & -0.82 & 0.68 & -0.91 & 0.23 & 0.88 \\
\hline MGS & 0.18 & 0.75 & 0.60 & 0.83 & -0.48 & 0.92 \\
\hline TOC & 0.14 & 0.90 & 0.84 & 0.90 & -0.32 & 0.92 \\
\hline $\mathrm{Fe}$ & 0.54 & 0.71 & 0.81 & 0.90 & -0.38 & 0.96 \\
\hline $\mathrm{Na}$ & 0.58 & 0.34 & 0.50 & 0.80 & -0.49 & 0.88 \\
\hline $\mathrm{Mg}$ & 0.89 & 0.37 & 0.93 & 0.69 & -0.69 & 0.97 \\
\hline$M n$ & 0.79 & 0.09 & 0.64 & 0.65 & -0.70 & 0.93 \\
\hline $\mathrm{Ba}$ & 0.75 & 0.30 & 0.66 & 0.25 & -0.93 & 0.94 \\
\hline $\mathrm{Sr}$ & 0.86 & -0.05 & 0.75 & 0.36 & -0.89 & 0.93 \\
\hline$\%$ Variance & 38.3 & 32.8 & & 54.7 & 38.3 & \\
\hline
\end{tabular}

mean grain size $(0.75)$ and total organic content $(0.90)$. Meanwhile, for KR2, varifactor VF1 explained $54.7 \%$ of the total variance with strong loadings on MGS (0.83), total organic carbon (0.90), and metal, namely, Fe (0.90) and $\mathrm{Na}(0.80)$, whereas varifactor VF2 accounted for $38.3 \%$ with negative loadings exhibited by the concentrations of Ba and Sr. The PCA shows that only Fe and $\mathrm{Na}$ are influenced by changes in MGS and organic content. In this study, communalities of the variance explained a higher value for KR2 (0.88-0.97) than KR1 (0.50-0.93), revealing that the extracted factor fitted well with factor solution.

It is noteworthy that a distribution pattern of metal content versus sample depth was clearly observed in KR2 (Fig. 5b) compared to KR1 (Fig. 5a). Two clusters were formed in KR2 in which metal accumulation in the upper depths had a higher concentration. The relationship between metal (Fe, Na) and MGS or organic content was much stronger for KR2 than KR1. This was highlighted by a straight line with a similar direction on the biplot graph (not shown). We deduce from this the relationship that the accumulation of finer-grained sediments following meander cut-off is favorable to binding between metals and organic matter.

The long-term (multi-decadal) mobility of mangrove tidal channels has been shown to depend essentially on sediment inputs into the system, which alters the morphodynamics of meanders, thus eventually generating, over even longer timescales (secular to millennial) the gradual reworking of mangrove tidal flats (Anthony 2004). Active meander belt reworking in mangrove swamps occurs where high sediment loads in channels, notably bedload, induces instability in flow conditions. This has probably been the case in the Kerteh channel, given the "abrupt" morphology of the meander cut-off (Fig. 1). The foregoing study of sediments associated with the tidal channel in the Kerteh Sungai mangrove swamp has shown that channel dynamics can be 

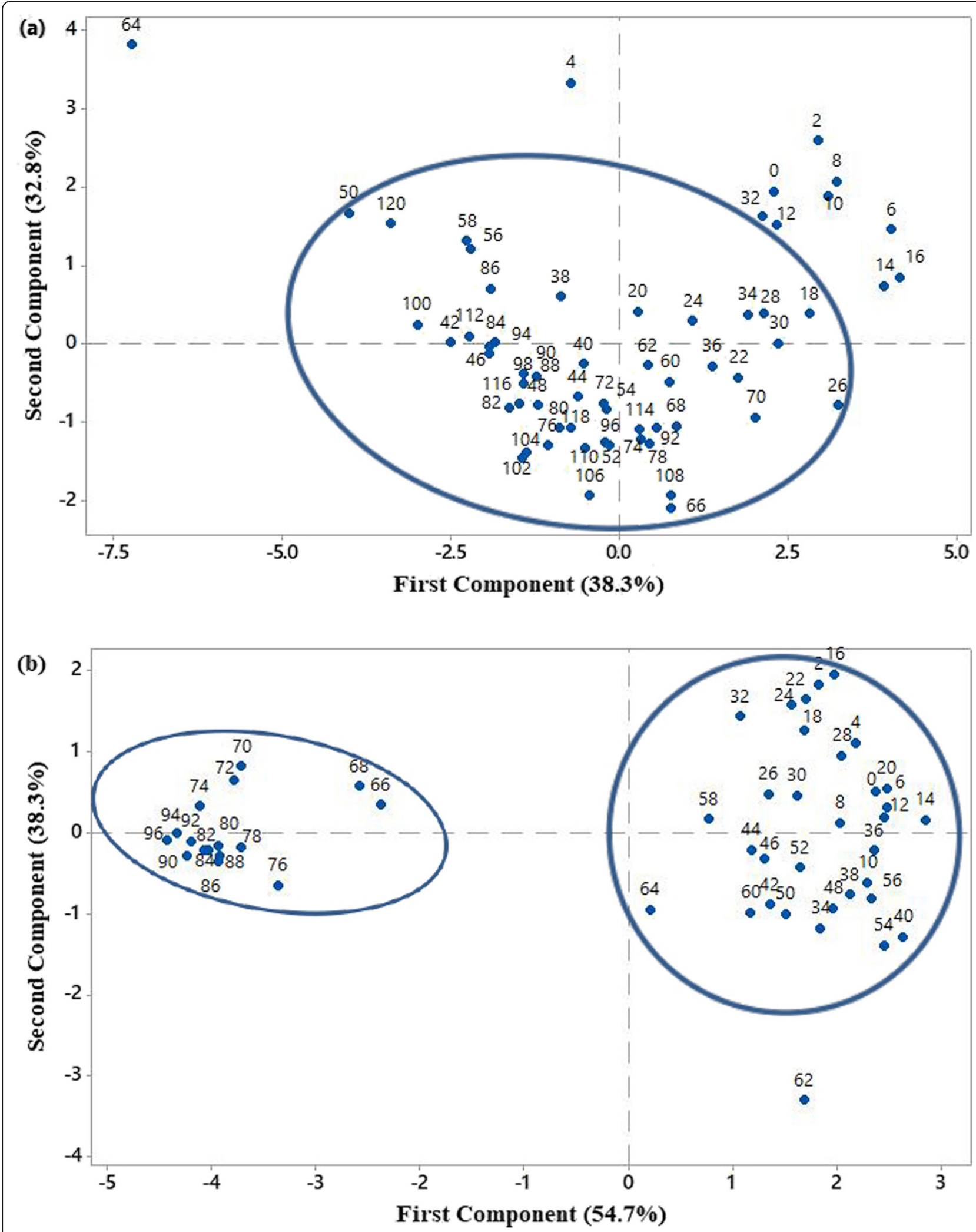

Fig. 5 Loading plot of selected metals concentrations vs depth on KR1 (a) and KR2 (b) 
important in generating variability in the sedimentology and geochemistry of mangrove sediments. The reasons for the formation of a meander cut-off in this swamp are not clear. However, since its formation, the Kerteh channel and its meander cut-off have exhibited apparent stability at the timescale of available satellite images and aerial photographs covering the study area (13 years). This stability suggests that the swamp and its channel network may now be largely in equilibrium with flow conditions.

\section{Conclusions}

This study has shown that geomorphic changes in mangrove tidal channels can generate significant variations in sediment characteristics and geochemistry. The data from two cores in contrasting local geomorphic situations associated with channel meandering show clear trends in metal concentrations, MGS and sorting, and TOC. The most noteworthy aspect highlighted by the study is that abrupt changes in channel flow conditions generated by a meander cut-off can induce marked changes in the sedimentology and geochemistry of sediments over time. Spatio-temporal changes in the dynamics of tidal channels in mangrove swamps are, thus, an important mechanism in generating variability in the long-term sedimentology and geochemistry of mangrove sediments.

\section{Abbreviations}

MGS: Mean grain size; ICP-MS: Inductively coupled plasma mass spectrometer; NBS: National Bureau of Standard; USDA: United States Department of Agriculture

\section{Acknowledgements}

This work was supported by the Research Acculturation Grant Scheme (RAGS) [Vot. 57097, 2013]. The author would like to thank Mr. Syed Shahrul Afzan Syed Bidin and Mr. Yuzwan Mohammed, staff of Faculty of Science and Marine Environment, and Institute of Oceanography and Environment (INOS), Universiti Malaysia Terengganu for their assistance in this project.

\footnotetext{
Authors' contributions

Shari $\mathrm{H}$. conceived of the presented idea, developed the theory, performed the computations, verified the analytical methods, and in charge of overall direction and planning. He also encouraged Nasir Q.M. and Naim E. to investigate the geochemical compounds and supervised them in order to accomplish the findings of this work.

Nasir Q.M. carried out the experiment, wrote the manuscript with supporting idea from Hasrizal Shaari.

Hui-Juan P helped in improving this manuscript by giving the critical thinking about the discussion and suitability of some old data in the original manuscript.

Mohamed C.A.R. carried out the experiment analysis in his laboratory at Universiti Kebangsaan Malaysia.

Yusoff A.H. helped interpretation and wrote the discussion of the modern condition in the study area.

Khalid W.M.A.W.M. provided the statistical analysis of data and carried out the calculations.

Naim E. carried out the experiment, wrote the manuscript with support from Hasrizal Shaari.

Setiawan R.Y. provided critical feedback and helped shape the research, analysis, and manuscript.
}

Anthony E.J. contributed on conceptual ideas and proof outline. He verified the data and wrote the important part of the discussion with input from all authors.

The author(s) read and approved the final manuscript.

\section{Funding}

This work was supported by the Research Acculturation Grant Scheme (RAGS) [Vot. 57097, 2013].

\section{Availability of data and materials}

The datasets used and/or analyzed during the current study are available from the corresponding author on reasonable request.

\section{Competing interests}

The authors declare that they have no competing interests.

\section{Author details}

${ }^{1}$ Faculty of Science and Marine Environment, Universiti Malaysia Terengganu, 21030 Kuala Nerus, Terengganu, Malaysia. ${ }^{2}$ Institute of Oceanography and Environment, Universiti Malaysia Terengganu, 21030 Kuala Nerus, Terengganu, Malaysia. ${ }^{3}$ Institute of Earth Science, College of Ocean Science and Resource, National Taiwan Ocean University, Keelung, Taiwan. ${ }^{4}$ Center of Excellence for Ocean Engineering, College of Engineering, National Taiwan Ocean University, Keelung, Taiwan. ${ }^{5}$ Faculty of Science and Technology, Universiti Kebangsaan Malaysia, 43600 Bangi, Selangor, Malaysia. ${ }^{6}$ Faculty of Bioengineering and Technology, Universiti Malaysia Kelantan, 17600 Jeli, Kelantan, Malaysia. ${ }^{7}$ Department of Fisheries, Faculty of Agriculture, Universitas Gadjah Mada, J. Flora Gd. A4, Bulaksumur, Yogyakarta 55281, Indonesia. ${ }^{8}$ UM 34 CEREGE, CNRS, IRD, INRA, Collège de France, Aix Marseille University, Aix-en-Provence, France. ' USR LEEISA, CNRS, Cayenne, French Guiana, France.

Received: 5 May 2020 Accepted: 18 August 2020

Published online: 07 September 2020

\section{References}

Abdul Razak NS, Shaari H, Husain ML, Minhat Fl, Mohd Azmi MF (2018) Vertical profile of heavy metals in mangrove and lagoon sediment cores of Sungai Kilim, Langkawi, Malaysia. Pollut Res 37(1):41-50

Allen JRL (2000) Morphodynamics of Holocene salt marshes: a review sketch from the Atlantic and Southern North Sea coasts of Europe. Quat Sci Rev 19: 1155-1231. https://doi.org/10.1016/S0277-3791(99)00034-7

Allison LE, Moodie CD (1965) Carbonate in methods of soil analysis. In: Black CA (ed) Chemical and Microbiological Properties. Soc. Agron. Inc. Madison, Wisconsin, pp 1387-1388

Anthony EJ (2004) Sediment dynamics and morphological stability of an estuarine mangrove complex: Sherbro Bay, West Africa. Mar Geol 208:207224. https://doi.org/10.1016/j.margeo.2004.04.009

Anthony EJ (2009) Shore processes and their palaeoenvironmental applications: chapter 3: tidal flats. Developments in Marine Geology Volume 4. Elsevier, Amsterdam, p 519

Anthony EJ, Lang J, Oyédé LM (1996) Sedimentation in a tropical, microtidal, wave-dominated coastal-plain estuary. Sedimentology 43:665-675. https:// doi.org/10.1111/j.1365-3091.1996.tb02019.x

Argyris J, Faust G, Haase M (1994) An exploration of chaos. An introduction for natural scientists and engineers. Texts Computer Mechanic 7. Elsevier, New York, p 751

Camporeale C, Perucca E, Ridolfi L (2008) Significance of cutoff in meandering river dynamics. J Geophys Res 113(F01001):1-11. https://doi.org/10.1029/ 2006JF000694

Chan NW (2012) Impacts of disasters and disasters risk management in Malaysia: the case of Floods. In: Sawada Y, Oum S (ed), Economic and welfare impacts of disasters in East Asia and policy responses. ERIA Research Project Report 2011-8, Jakarta, p 503-551.

Cohen MCL, Lara RJ, Cuevas E, Oliveras EM, da Silveira SL (2016) Effects of sealevel rise and climatic changes on mangroves from southwestern littoral of Puerto Rico during the middle and late Holocene. Catena 143:187-200. https://doi.org/10.1016/j.catena.2016.03.041

Droppo IG, D'Andrea L, Krishnappan BG, Jaskot C, Trapp B, Basuvaraj M, Liss SN (2015) Fine-sediment dynamics: toward an improved understanding of 
sediment erosion and transport. J Soils Sediments 15(2):467-479. https://doi. org/10.1007/s11368-014-1004-3

Edwards BF, Smith DH (2002) River meandering dynamics. Physic Rev E 65:46303. https://doi.org/10.1103/PhysRevE.65.046303

Ellison AM, Farnsworth EJ (1997) Simulated sea level change alters anatomy, physiology, growth, and reproduction of red mangrove (Rhizophora mangle L.). Oecologia 112:435-446. https://doi.org/10.1007/s004420050330

Ellison J, Stoddart D (1991) Mangrove ecosystem collapse during predicted sea level rise: Holocene analogues and implications. J Coast Res 7:151-165

Ferguson RI (1984) The threshold between meandering and braiding. In: Smith KVH (ed) Channels and Channel Control Structures. Springer, Berlin, Heidelberg, pp 90-125

Fleming BW (2017) Particle shape-controlled sorting and transport behavior of mixed siliciclastic/bioclastic sediments in a mesotidal lagoon, South Africa. Geo-Marine Let 37:397-410. https://doi.org/10.1007/s00367-016-0457-3

Folk RL, Ward WC (1957) Brazos River bar: a study in the significance of grain size parameters. J Sediment Petrol 27:3-26. https://doi.org/10.1306/74D706462B21-11D7-8648000102C1865D

França MC, Alves ICC, Castro DF, Cohen MC, Rossetti DF, Pessenda LCR, Lorente FL, Fontes NA, Junior AÁB, Giannin PCF, Francisquini MI (2015) A multi-proxy evidence for the transition from estuarine mangroves to deltaic freshwater marshes, Southeastern Brazil, due to climatic and sea-level changes during the late Holocene. Catena 128:155-166. https://doi.org/10.1016/j.catena.2015. 02.005

Friedman GM, Johnson KG (1982) Exercises in sedimentology. Wiley, New York

Hooke JM (1977) The distribution and nature of changes in river channel patterns: the example of Devon. In: Gregory KJ (ed) River Channel Changes. Wiley, New York, pp 265-280

Howard AD (2009) How to make a meandering river. Proc Natl Acad Sci U S A 106(41):17245-17246. https://doi.org/10.1073/pnas.0910005106

Jackson RG (1978) Preliminary evaluation of lithofacies models for meandering alluvial streams. In: Miall AD (ed) Fluvial Sedimentology. Canadian Society Petroleum Geologist Memoir 5, p 543-576.

Jicknells TD, Kump AH (1984) The distribution and geochemistry of some trace metals in the Bermuda coastal environment. Estuar Coast Shelf Sci 18:245262. https://doi.org/10.1016/0272-7714(84)90070-2

Kamaruzzaman BY (1999) Geochemistry or the marine sediments. Its Paleoceanographic significance. Ph.D. Thesis, Hokkaido University, Hokkaido, unpublished.

Karbassi AR, Nabi-Bidhend GR, Bayati I (2005) Environmental geochemistry of heavy metals in sediment core off Bushehr, Persian Gulf. Iran J Environ Health Sci Eng 2:255-260

Leopold LB, Wolman MG (1960) River meanders. Geol Soc Am Bull 6:769-793

Liu CW, Lin KH, Kuo YM (2003) Application of factor analysis in the assessment of groundwater quality in a blackfoot disease area in Taiwan. Sci Total Environ 313(1-3):77-89. https://doi.org/10.1016/S0048-9697(02)00683-6

Louma SN (1990) Processes affecting metal concentrations in estuarine and coastal marine sediments. In: Furness RW, Rainbow PS (eds) Heavy Metals in the Marine Environment. CRC Press, Florida, pp 51-56

Morse JW, Presley BJ, Taylor RJ, Benoit G, Santschi P (1993) Trace metal chemistry of Galveston Bay: water, sediments and biota. Mar Environ Res 36:1-37. https://doi.org/10.1016/0141-1136(93)90087-G

Nguyen HL, Leemakers M, Elskens M, Ridder FD, Doan TH, Baeyens W (2005) Correlation, partitioning and bioaccumulation of heavy metals between different compartments of Lake Balaton. Sci Total Environ 341:211-226. https://doi.org/10.1016/j.scitotenv.2004.09.019

Noriki SK, Nakanishi T, Fukawa M, Uematsu T, Uchida H, Tsunogai S (1980) Use of a teflon vessel for the decomposition followed by determination of chemical constituents of various marine samples. Bull Fac Fish, Hokkaido Univ 31:354-465

Pusat Hidrografi Nasional (PHN) (2019) Jadual pasang surut Malaysia 2019

Ramos L, Hernandez LM, Gonzalez MJ (1994) Sequential fractionation of copper, lead, cadmium and zinc in soils from or near Donana National Park. J Environ Qual 23:50-57. https://doi.org/10.2134/jeq1994.00472425002300010009x

Schwenk J, Foufoula-Georgiou E (2016) Cutoffs accelerate nonlocal morphodynamic change. Geophys Res Lett 43(12):437-12,445. https://doi. org/10.1002/2016GL071670

Sutherland RA (1999) Distribution of organic carbon in bed sediments of Manoa Stream, Oahu, Hawaii. Earth Surf Process Landf 24: 571-583. doi:10.1002/ (SICI)1096-9837(199907)24:7\%3C571::AID-ESP975\%3E3.0.CO;2-F
U.S. Department of Agriculture (USDA) (1987) Agricultural resources: cropland, water and conservation situation and outlook report. AR-Economy Research Service, Washington, D.C.

Walkley A, Black IA (1934) An examination of Degtjareff method for determining soil organic matter, and proposed modification of the chromic acid tritation method. Soil Sci 37:29-38. https://doi.org/10.1097/00010694-19340100000003

Williamson F (2016) The "Great Flood" of 1926: environmental change and postdisaster management in British Malaya. Ecosys Health Sustain 2(11):e01248. https://doi.org/10.1002/ehs2.1248

Woodroffe C (1992) Mangrove sediments and geomorphology. In: Robertson Al, Alongi DM (eds) Tropical Mangrove Ecosystem. American Geophysical Union, Washington D.C., pp 7-41. https://doi.org/10.1029/CE041 p0007

Woodroffe CD, Rogers K, McKee KL, Lovelock CE, Mendelssohn IA, Saintilan N (2016) Mangrove sedimentation and response to relative sea-level rise. Annu Rev Mar Sci 8:243-266. https://doi.org/10.1146/annurev-marine-122414034025

\section{Publisher's Note}

Springer Nature remains neutral with regard to jurisdictional claims in published maps and institutional affiliations.

\section{Submit your manuscript to a SpringerOpen ${ }^{\circ}$ journal and benefit from:}

- Convenient online submission

- Rigorous peer review

- Open access: articles freely available online

High visibility within the field

- Retaining the copyright to your article

Submit your next manuscript at $\boldsymbol{\nabla}$ springeropen.com 